Діброва Т.Г.

канд. економ. наук, доцент

Національний технічний університет Украӥни «КПI»

Гараніна I.I.

Відкритий міжнародний університет розвитку людини «Украӥна»

\title{
СИСТЕМНИЙ ПІДХІД ДО ВДОСКОНАЛЕННЯ ПЕРЕГОВОРНОГО ПРОЦЕСУ В ОСОБИСТИХ ПРОДАЖАХ
}

\section{СИСТЕМНЫЙ ПОДХОД К УСОВЕРШЕНСТВОВАНИЮ ПЕРЕГОВОРНОГО ПРОЦЕССА В ЛИЧНЫХ ПРОДАЖАХ}

\section{SYSTEMIC APPROACH TO IMPROVING THE NEGOTIATION PROCESS IN PERSONAL SALES}

Однією з головних проблем здійснення особистих продажів $є$ необхідність підвищення ефективності переговорного процесу. Адже кожна зі сторін - ие індивіди, які мають відповідний соиіальний статус та тип особистості Це зобов'язує продавців уміти встановлювати стосунки та вести переговори у форматі, який помагає контактувати й аргументовано відповідати на запитання клієнта.

Стаття присвячена аналізу сучасних методів, підходів та технік ведення переговорів, щьо дають змогу не тільки отримати додаткову інформачію про мотивачію та потреби клієнта, його особистість, а $і$ гнучко реагувати на запити клієнта, оперативно вносити відповідні корективи в процес спілкування. $B$ статті пропонуються рекомендації з удосконалення як форми, так $i$ змісту переговорного процесу. Так, при проведенні переговорів необхідно враховувати тональність та манеру розмови, жестикуляцію та уподобання клієнтів, індивідуальні характеристики, тип особистості співрозмовника, щзо розглядаються в техніках «приєднання». Удосконалення змістовної частини переговорного процесу полягає у застосуванні спеціальних методик, підходів та технік, що здатні налагодити контакт і переконати клієнта в правильності вибору - ие техніки опитування, прийоми «активного» слухання, підходи до подолання заперечень. Підсумовуючи, можна стверджувати, щзо розглянуті у статті сучасні методи, підходи та техніки, які трунтуються на комплексному та системному їх застосуванні в процесі здійснення особистих продажів, призведе до вдосконалення переговорного прочесу.

Ключові слова: особистий продаж, техніки приєднання, техніки опитування, прийоми «активного» слухання, підходи до подолання заперечень.

Одной из главных проблем персональных продаж является необходимость повышения эффективности переговорного процесса. Ведь каждая из сторон этого процесса - это индивидь, имеющие соответствующий статус и тип личности. Это требует от продавиа умения ведения переговоров в формате, который помогает контактировать и аргументировано отвечать на запроси клиента.

Статья посвящена анализу современных методов, подходов и техник ведения переговоров, которые дают возможность не только получить дополнительную объективную информацию о мотивациях клиентов, но и гибко реагировать на его запроси 
и оперативно вносить коррективы в прочесс общения. Предлагаются рекомендации по усовершенствованию формы и содержания переговорного прочесса. Так, при проведении переговоров необходимо учитывать тональность, манеру говорить, предпочтения $и$ индивидуальные характеристики клиента, которые рассматриваются в техниках «присоединения». Повышение эффективности содержание переговорного прочесса предполагает использование современных техник опроса, приёмов «активного» слушания u «преодолению возражений». Подводя итоги, можно сделать выводы о том, что рассмотренные в статье современные подходы, методы и техники, основанные на системном использовании приведет к усовершенствованию переговорного процесса.

Ключевые слова: личная продажа, техники присоединения, техники опроса, приемы «активного» слушания, подходы к преодолению возражений.

A major problem in the implementation of personal selling is need to improve the negotiation process. Each party - is individuals who have appropriate social status and personality type This requires the seller to be able to establish relationships and negotiate in a format that helps communicate and reasonably answer the questions of the client.

This article analyses the modern methods, approaches and techniques of negotiation. Such approaches allow for more information about the motivation and needs of the client, his personality. Also, these approaches allow flexibility to respond to customer requests promptly make appropriate adjustments in the communication process. The paper offers recommendations for improving the form and content of negotiations. When negotiations must take into account the tone and style of conversation, gestures and preferences of customers, individual characteristics, personality type counterpart. These features take into account the technique of "accession". Improving the content of the negotiations is to use special techniques, approaches and techniques. Such techniques, approaches and techniques can make contact and convince a customer right choice. This is a technology survey techniques "active" listening approaches to overcome objections. In summary, it can be argued that the article in question will lead to improvements in the negotiation process.

Keywords: personal selling, engineering joining technology, survey techniques, "active" listening, approaches to overcome objections.

Вступ. Незважаючи на існування різних підходів до планування та реалізації особистих продажів, можна стверджувати, що на сьогодні теоретичні та практичні питання підвищення ефективності переговорного процесу потребують додаткового дослідження. Проте, більшість науковців розглядають процес здійснення особистих продажів як поетапний, який потребує використання спеціальних комунікаційних прийомів на кожному 3 етапів. Прихильниками такого підходу є С. Мориарті, Ф. Котлер, А. Старостіна, П. Дойль, В. Салій, С. Ребрик тощо.

За ступенем застосування $\mathrm{i}$ ефективністю особистий продаж $\epsilon$ домінуючим інструментом маркетингових комунікацій на промисловому ринку. Загальна процедура здійснення продажів передбачає: пошук i оцінювання потенційних покупців; попередню підготовку переговорного процесу; встановлення контакту; власно, проведення переговорів; завершення переговорів, укладення угоди та ii супровід. По суті, процес продажу починається 3 третього етапу - встановлення контакту, а його 
основне комунікаційне навантаження відбувається на етапі проведення переговорів.

Постановка завдання. Характер угоди на промисловому ринку має масштабний і довгостроковий характер, це потребує спеціальної підготовки продавця, підвищення його кваліфікації за рахунок застосування сучасних методів та технік ведення переговорів. Сутність вдосконалення процесу перемовин полягає у виявленні та розумінні проблем клієнта, набутті навичок та вмінь в доведенні до нього інформації, яка б відповідала його висловленим або невисловленим сподіванням і потребам.

Оскільки характер персональних продажів як особистої комунікації передбачає можливість iї адаптації до умов продажів, застосування сучасних методів ведення переговорів дають можливість одержати інформацію про зміну мотивацій та потреб клієнтів, активність конкурентів, необхідність адаптації пропозиції або умов продажу. Отже, завданнями дослідження $є$ аналіз та систематизація сучасних методів, підходів та технік, застосовуваних у переговорах та розроблення рекомендацій щодо їх застосування в особистих продажах.

Методологія. Методологічною базою проведеного дослідження $\epsilon$ системний підхід, сучасні науково-теоретичні положення теорії маркетингу та психології, практичні методи пізнання: порівняльний аналіз і метод логічного узагальнення, що найбільше відповідають тематиці проведеного дослідження. Отримана, в результаті дослідження, інформація подана в графічній формі.

Результати дослідження. Успішне укладання угоди на промисловому ринку цілком залежить від того чи знає продавець яким чином на підприємстві ухвалюється рішення про закупівлю, хто бере участь в ухваленні його рішення, що впливає на вибір покупців. Відповідно у процесі здійснення особистих продажів варто враховувати особливості поведінки споживачів. Розглянемо докладніше чинники, що впливають на поведінку споживача на промисловому ринку та формують мотиваційне поле потенційного клієнта. Більшість фахівців виокремлюють організаційні, ситуаційні, міжособистісні та індивідуальні фактори $[1,2,7]$.

Під час ухвалення рішення про закупівлю визначальними $\epsilon$ організаційні фактори до яких відносяться ринкові характеристики підприємства (розмір, форма власності, характер діяльності, обсяги виробництва/закупівель), організаційна структура підприємства, його фінансові можливості тощо.

На поведінку споживачів впливають також ситуація здійснення покупки. За умови першого контакту поведінка клієнта має характер широкого вибору, яка пов'язана з високим ступенем ризику при ухваленні рішення про покупку. Модель поведінки обмеженого вибору обумовлена зниженням ступеня ризику, при здійсненні покупки. На таких споживачів впливають 
імідж/репутація компанії, досвід роботи, рекомендації колег по бізнесу. При звичайній повторній покупці відомого товару поведінка споживачів має традиційний характер. На такого покупця певною мірою впливають особисті, ділові, доброзичливі контакти, система знижок тощо. 3 огляду на підвищення ефективності особистих продажів слід враховувати, що ухвалення рішення про закупівлю здійснюється закупівельним центром. Складність роботи 3 такою структурною одиницею, як закупівельний центр, вимагає урахування міжособистісних та індивідуальних факторів.

Саме вони визначають успіх процесу переговорів і дають можливість встановити тривалі відносини 3 клієнтами. Міжособистісні фактори допомагають враховувати повноваження та статус осіб, які входять у закупівельний центр, їхню мотивацію. Це формує бажаний імідж продавця й дає змогу знайти переконливий тон і стиль переговорів. Не менш важливі індивідуальні фактори. Вони враховують індивідуальні характеристики учасників процесу переговорів, рівень їх освіти, досвід роботи, характер мислення, інтереси, погляди і полегшують процес спілкування між продавцем і покупцем. Отже, результативність особистих продажів цілком залежить від урахування цих факторів, які відображаються на переговорному процесі.

Сконцентруємо увагу на третьому етапі особистих продажів, власне процесі проведення переговорів, який є ключовим у досягненні кінцевого результату - підписання угоди. Етап складається 3 досягнення певних результатів: встановлення особистих контактів 3 клієнтом, уточнення його мотивацій, демонстрації/презентації продукту, обговорення пропозицій та подолання заперечень.

Шляхи вдосконалення процесу переговорів полягають у застосуванні сучасних технік, прийомів та методів в особистих продажах.

По-перше, при встановленні контакту в процесі особистого продажу можна скористатися техніками «приєднання». Вони засновані на необхідності визначення стереотипу поведінки, манери слухати, говорити, стилю мовлення, міміки та жестикуляції співрозмовника. Настрій клієнта, емоційна складова, темп та тон мовлення, наявність певних мотиваційних установок, психологічних, утилітарних, особистих цілей також визначає форму та емоційне наповнення переговорного процесу. Застосування технік грунтується на тому, що спілкування між продавцем і клієнтом відбувається за трьома каналами: вербальним, візуальним і паравербальним. Через вербальний канал співрозмовник може отримати інформацію тільки про те, що людина свідомо хоче йому донести, тобто значення слів, логіку пропозицій. Через візуальний канал (міміку, жести, зовнішній вигляд, спрямованість погляду) продавець доносить до співрозмовника латентну інформацію - ставлення до слів, дій, емоції, внутрішню мотивацію. 
Паравербальний, або звуковий, канал за допомогою тону, інтонації, швидкості мови, пауз i мелодійності мови може багато розповісти досвідченому продавцеві-комунікатору. Так, продавцеві слід уважно ставитись до всіх каналів - візуальний i паравербальний допомагають дізнатися не тільки про ставлення до співрозмовника, а й його внутрішні конфлікти (табл.). Під час сприйняття інформації з усіх каналів домінують візуальний (58\%) і паравербальный (35\%), вербальний канал становить близько 7\% [3]. Сукупний аналіз інформації, отриманої за всіма каналами, дасть змогу продавцеві правильно оцінити відповідну реакцію покупця. Техніки приєднання не тільки полегшують встановлення контакту, а й рекомендуються до використання на всіх етапах процесу переговорів.

Таблиця

Складові «технік присднання» в особистому продажу

\begin{tabular}{|l|l|l|l|l|}
\hline Подих & Голос & Мова & $\begin{array}{l}\text { Фізична } \\
\text { подоба }\end{array}$ & Схожий світогляд \\
- ритм & - тон & - ключові & - поза & - цінності \\
- темп & - темп & слова & - жести & - переконання \\
- глибина & - гучність & - манера & - міміка & - ідентичність \\
- рівень & - паузи & говорити & - ритм рухів & - загальний досвід \\
& & - спільні інтереси \\
\hline
\end{tabular}

По-друге, першим контактом з клієнтом також слід скористатися для уточнення потреб і проблем споживача. При встановленні контакту необхідно «розговорити» співрозмовника, змусити його ставити питання. Це дасть можливість виявити потреби й бажання клієнта, довідатися про можливі заперечення та підсвідому мотивацію. Скориставшись техніками опитування цей процес можна також вдосконалити.

Техніки опитування досить умовно можна розділити на прості та комплексні (зображено на рис.). До перших відносяться застосування різних форм запитань:

- Відкриті запитання допомагають залучити клієнта до розмови. Вони починаються зі слів: Хто? Що? Як? Скільки?

- Закриті запитання рекомендується використовувати, для того щоб направляти і контролювати хід бесіди. Це запитання на кшталт «Чи не так?», «Ви згодні?», «Правда, що...?»

- Альтернативні запитання допомагають отримати згоду клієнта. Це питання 3 двома варіантами відповіді, причому обидва підштовхують клієнта до здійснення угоди.

- Питання-залучення - це будь-яке позитивне запитання про товар, яким клієнт, можливо, буде перейматися після покупки. Такі питання дають змогу непомітно підштовхнути клієнта до позитивної оцінки продукту.

- Уточнювальні запитання допомагають з'ясувати проблеми клієнта. 
Найпопулярнішою серед фахівців $\epsilon$ методика комплексного опитування клієнтів «SPIN» від перших літер англійських слів situation (ситуація), problem (проблема), implication (наслідки), need-payoff (віддача), запропонована Н. Рикхемом і Ш.Д. Моргеном [4]. Ця методика, орієнтована на покупця, включає чотири типи запитань, які доцільно ставити клієнту в певній послідовності - про ситуацію, про проблеми, про наслідки, про віддачу. Ці питання фіксують увагу клієнта на його проблемі та на можливості іiі розв'язати за допомогою пропонованого товару.

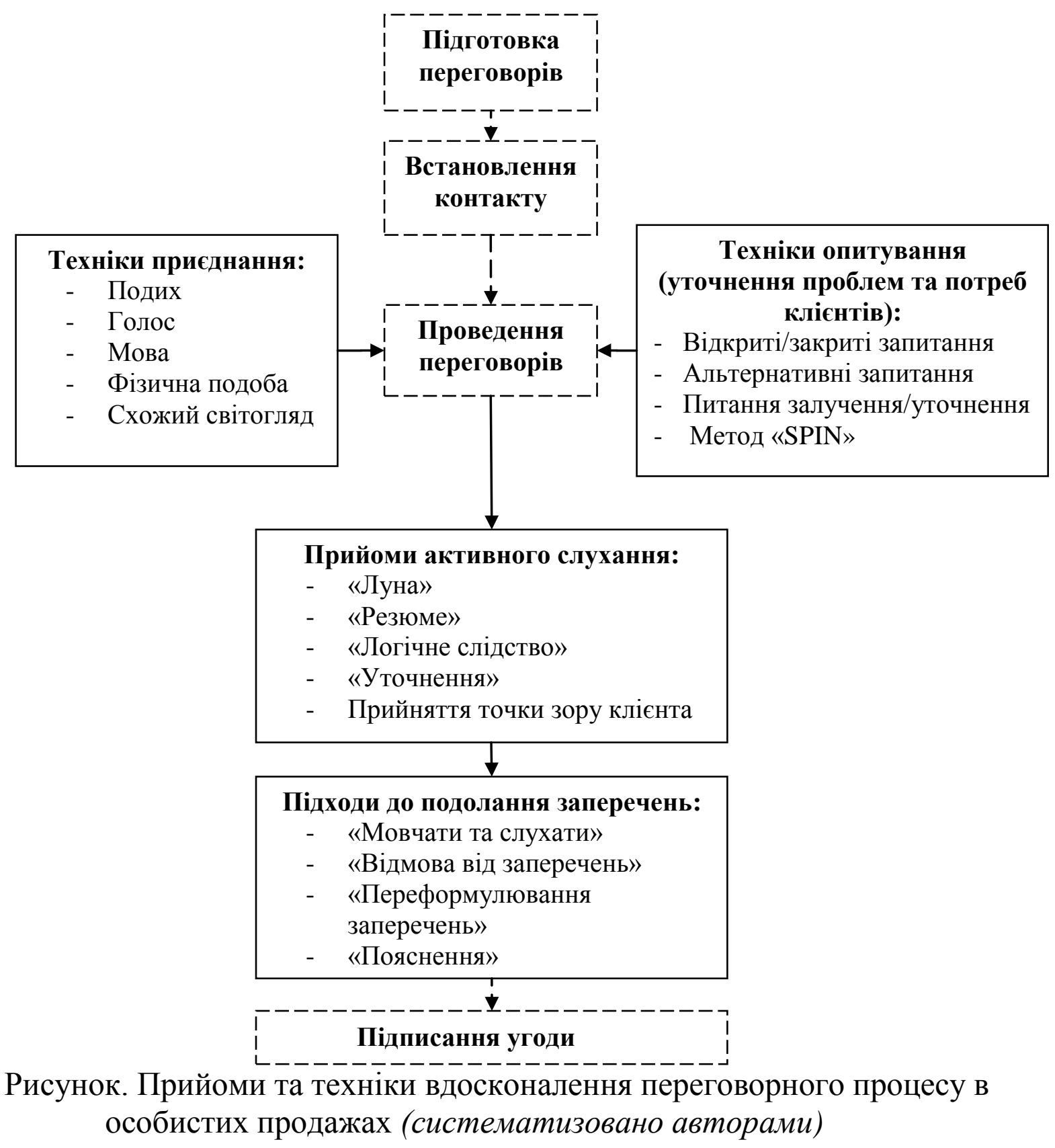


Підвищення ефективності застосування методики базується на врахуванні, як раціональних так і емоційних мотивацій, якими керуються клієнти. До раціональних мотивів можна віднести: ціну, споживчі характеристики товару, власне його техніко-експлуатаційні характеристики, умови доставки товару, монтаж, технічну підтримку, ремонт, форму оплати, умови та обсяги поставок тощо. До емоційних відносяться репутація/імідж підприємства, безпека й зручність співробітництва, симпатія до співробітників компанії тощо.

Техніка «SPIN» - $\epsilon$ найефективнішим способом переходу до презентації пропозиції продавця. Вдала презентація продукції/проектів як складова переговорного процесу $є$ запорукою його успіху і включає прийоми та техніки, що підвищують іiі ефективність. Проте, це є темою окремого дослідження.

Вміння слухати - це наступне завдання продавця, третя можливість поліпшення стосунків 3 клієнтом. Демонстрація вміння уважно слухати у поєднанні 3 техніками приєднання справляє більше враження, ніж уміння говорити. Наведемо найпопулярніші прийоми «активного» слухання [7] (рисунок). До них належать:

- прийом «Луна» - дослівне повторення продавцем основних положень та висловлювань клієнтів;

- прийом «Резюме» - відтворення слів клієнта в короткому й узагальненому вигляді;

- прийом «Логічне слідство» - продавець виводить логічне слідство 3 висловлень клієнта;

- прийом «Уточнення» - прохання конкретніше охарактеризувати окремі положення, які висловлює клієнт; прийом «прийняття точки зору клієнта» - на відміну від мовчазної згоди 3 пропозицією клієнта таке прийняття $\epsilon$ демонстрацією розуміння думок клієнта, а вже після цього можливістю реалізувати своє право його переконувати.

В четверте, практично завжди під час проведення переговорів клієнт висловлює свої заперечення, ставитися до яких необхідно як до бажання одержати повнішу інформацію щодо комерційної пропозиції, а як до прояву агресії клієнта. Отже, рекомендуємо до застосування (рисунок) такі підходи «подолання заперечень»:

- Перший підхід, «мовчати й слухати», передбачає демонстрацію зацікавленості і бажання зрозуміти клієнта вникаючи в суть заперечень.

- Другий підхід базується на твердженні - клієнт завжди правий. Якщо він помиляється, можна висловити заперечення йому, скориставшись «словами-містками» - «звичайно», «без сумніву», «може бути», «як правило». Вони полегшать заперечення і не будуть дратувати клієнта. Лексика має бути зрозуміла клієнтові, не ускладнювати мову. 
- Третій підхід, «переформулювання заперечення», має на меті пом'якшення заперечення, замінити «заперечення» «сумнівом».

- Четвертий підхід, «прохання пояснень» має на меті перепитуючи клієнта, ставити питання так, щоб він сам відповідав на свої запитання «чому?».

Висновки. Отримані в статті результати довели що застосування сучасних методів, підходів та технік розроблених на основі теорії комунікацій 3 урахуванням психологічних особливостей переговорного процесу будуть сприяти підвищенню ефективності особистих продажів. По-перше, ключовою ланкою особистих продажів $є$ етап проведення переговорів, який включає знайомство, перший особистий контакт між продавцем та клієнтами, обмін думками, презентацію комерційної пропозиції та ії обговорення. Отже, шляхи підвищення ефективності переговорного процесу лежать в площині удосконалення як форми так i змісту проведення переговорів. По-друге, форма проведення переговорів має враховувати тональність розмови, акценти та способи переконання співрозмовника. полягає у застосуванні спеціальних методик, підходів та технік, що здатні налагодити контакт і переконати клієнта в правильності вибору. По-третє, при застосуванні технік опитування, активного слухання та подолання заперечень належить зосередити увагу на одній провідній ідеї, яку мають правильно зрозуміти клієнти. Завдання продавця $\epsilon$ створення/підтримка певної схеми сприйняття конкретного продукту, на основі якої споживач може побудувати свою поведінку, грунтовану на ціннісних орієнтирах, які залежать від соціального статусу, образу життя, оточення клієнта. Четверте, в процесі проведення переговорів необхідно враховуватись індивідуальні характеристики та тип особистості співрозмовника. Застосування технік приєднання при встановленні особистого контакту є обов'язковою умовою позитивного контакту з клієнтом.

Отже, застосування методів і технік наведених у статті полегшують продавцям процес встановлення стосунків і ведення переговорів у форматі, який помагає контактувати й аргументовано відповідати на запитання клієнта.

\section{Література:}

1. Промисловий маркетинг. Теорія та господарські ситуації : підруч. / за ред. А.О. Старостіної. - К. : Іван Федоров, 1997. — 400 с.

2. Дойль П. Маркетинг-менеджмент и стратегии / Дойль П. - [3-е изд.]. - СПб. : Питер, 2002. — 560 с.

3. Мициг П. Как проводить деловые беседы / Мициг П. - М. : Экономика, 1987. $148 \mathrm{c}$. C. 31 .

4. Ребрик С. Тренинг профессиональных продаж / Ребрик С. - М. : Эксмо, 2002. -

5. Діброва Т.Г. Маркетингова політика комунікацій: стратегії, вітчизняна практика / Діброва Т.Г. - Навчальний посібник. - К.: Стилос, 2011. - 294с. 
6. Ламбен Ж.-Ж. Стратегический маркетинг. Европейская перспектива: Пер. с франц. - Спб.; М.; Наука, 1996. -XV 589 с.

7. Салий В.В. Искусство продаж : практикум / В.В. Салий, В.В. Бакаева. - М. : Издат. дом «Дашкова и Ко», 2000. - 164 с. 